\begin{tabular}{cc} 
Revista de & Journal of Integrated \\
GESTÃO COSTEIRA Integrada COSTAL ZONE MANAGEMENT \\
\hline \hline
\end{tabular}

\title{
Water mass characteristics in a shallow bank highly influenced by river discharges: the Sofala Bank in Mozambique
}

\author{
Fialho P.J. Nehama ${ }^{\circledR}$, a ; Muhamade Ali Lemos ${ }^{\mathrm{b}}$; Hélder Arlindo Machaieie ${ }^{\mathrm{a}}$
}

\begin{abstract}
Hydrological data collected between 2003 and 2007 were analysed in order to describe the water masses of the Sofala Bank in Mozambique Channel, a region under the influence of outflow from the Zambezi River. The data analysis consisted in the visual inspection of temperature and salinity combined with the analysis of variance for unbalanced data. Four water masses were identified, which differ in their location, temperature, and mainly salinity. These water masses are: (i) LSSW-low salinity shelf water that occurs at the upper $15 \mathrm{~m}$ and within $40 \mathrm{~km}$ from the coastline; (ii) WOSW- warmer oceanic surface waters that occurs throughout the bank at depths not exceeding 70m; (iii) DOW-deep oceanic waters that occur from the sub-surface layer to the seabed; and (iv) HSSW- high salinity shelf water that occurs offshore from $40 \mathrm{~km}$ at depths greater than $15 \mathrm{~m}$. In general, the water masses are well oxygenated with the lower limit of oxygen being 13, 7 and $5.7 \mathrm{~mL} / \mathrm{L}$ for the LSSW, WOSW, and the HSSW, respectively. Fluorescence levels are low and almost homogeneous in the LSSW, but it varies with depth in the other oceanic waters. The presence of four different water masses in the Sofala Bank is likely to have ecological and management implications.
\end{abstract}

Keywords: Water mass, Sofala Bank, Zambezi, Dissolved Oxygen, Fluorescence.

\section{Resumo}

Características das massas de água num banco pouco profundo altamente influenciado por descargas fluviais: o Banco de Sofala, em Moçambique.

Dados hidrológicos colhidos entre 2003 e 2007 foram analisados com o intuito de descrever as massas de água que ocorrem no Banco de Sofala no Canal de Moçambique, uma região sob influência das descargas do Rio Zambeze. A análise desses dados consistiu na inspeç̧ão visual da temperatura e salinidade combinada com a análise de variância para dados de tamanhos diferentes. Foram identificadas quatro massas de água, que se diferenciam pelo local de ocorrência, temperatura, e principalmente salinidade. As massas de água são: (i) LSSW-águas costeiras de baixa salinidade que ocorrem nos primeiros $15 \mathrm{~m}$ de profundidade e a $40 \mathrm{~km}$ da costa; (ii) WOSW-águas superficiais oceânicas de alta temperatura que ocorrem em todo banco a uma profundidade máxima de 70m; (iii) DOW-águas oceânicas profundas de baixa temperatura que ocorrem desde a camada subsuperficial até ao fundo; e (iv) HSSW-águas da plataforma com salinidade elevada que ocorrem a partir dos $40 \mathrm{~km}$ da costa a uma profundidade não inferior a 15m. No geral, as massas são bem oxigenadas, sendo o limite inferior de oxigénio de 13, 7 e $5.7 \mathrm{~mL} / \mathrm{L}$ para a LSSW, WOSW, e a HSSW, respectivamente. Os níveis de fluorescência são baixos e a distribuição é quase homogénea para LSSW, mas variável em profundidade nas águas oceânicas. A presença de quatro massas de água diferentes no Banco de Sofala tem provavelmente implicações ecológicas e de gestão de recursos.

Palavras-chaves: Massas de água, Banco de Sofala, Zambeze, Oxigénio Dissolvido, Fluorescência.

\footnotetext{
@ Corresponding author, to whom correspondence should be addressed: < fialho.nehama@uem.mz>

${ }^{a}$ Escola Superior de Ciências Marinhas e Costeiras, Universidade Eduardo Mondlane, C.P. 128, Chuabo-Dembe, Quelimane, Mozambique

${ }^{\mathrm{b}}$ Instituto Nacional de Investigação Pesqueira, Delegação de Nampula, Mozambique
}

* Submission: 9 OCT 2014; Peer review: 16 NOV 2014; Revised: 31 MAR 2015; Accepted: 12 MAY 2015; Available on-line: 14 MAY 2015
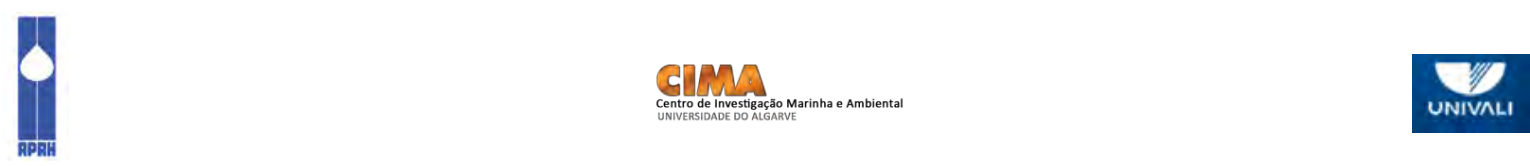


\section{Introduction}

The knowledge of water mass characteristics is important for the understanding of marine and coastal ecosystems, and the behaviour or marine organisms. In particular, coastal waters often receive many landderived contaminants that alter the manner in which services that includes fisheries, tourism, harbours, and others, can be provided to coastal communities. The water mass characteristics are more variable at the coast because of the influence of tidal currents, river runoff, local topography, seasonal climatic forcing, and the variable circulation patterns. Therefore, evaluating some fundamental hydrological properties of water masses in the coastal zone is a difficult task, mainly because of the dynamic complexity of these environments. In order to quantify properties of interest for the coastal zone management, researchers rely on assessing tracers for the mixing between different water masses and their transports. These tracers have to be readily measurable and often include temperature and salinity (Silva, 1984; Gammelsrod and Hoguane, 1995; Machaieie, 2012), as well as nutrients and trace elements (Ferreira et al., 2010; Santos et al., 2008; 2011).

Traditionally, a water mass is defined as a sizeable portion of water associated with a particular range of temperature $(\mathrm{T})$ and salinity $(\mathrm{S})$ values, which can be identified through a curve in a T-S diagram. Changes in salinity of seawater have remarkable impacts on marine organisms that must actively regulate their salt tolerance in order to maintain the body fluids in movement and also the ionic concentration different from of the surrounding environment (Pickard \& Emery, 1990; Malauene, 2005). The temperature of the water influences many physical, chemical and biological processes in the marine environment; it controls the setting where biological processes occur and determines the concentration of gases dissolved in seawater, including oxygen and carbon dioxide. Metabolism takes place faster in warmer water than in colder ones, and it only takes place within tolerable range of temperature. Temperature also is a major abiotic factor influencing the distribution of marine species (Lalli \& Parsons, 1997).

Sofala Bank is one of the most important ecological regions along the Mozambique coast on the western Indian Ocean, and a host for most of the mangrove and fishery resources of the country (Hoguane, 2007). The water masses in the Sofala Bank are characterized by the presence of (i) low salinity shelf water due to the strong influence of freshwater discharge from numerous rivers, the Zambezi River being the most important of all; (ii) oceanic water resulting from the mixing of equatorial and subtropical water masses transported by eddies in the Mozambique Channel; and (iii) high salinity shelf water formed by elevated evaporation in the mangrove swamps along the coast. Several studies allowed this characterization to be drawn, including the work of Brinca et al. (1983, 1984), Silva (1984), Gammelsrød \& Hoguane (1995), Hoguane (1997), and Machaieie (2012). According to these studies, the ranges of salinity for these three water masses are as follow, less than 34.8, between 34.8 and 35.4, and greater than 35.4 respectively.

The Zambezi River outlet is located in the Sofala Bank, on the western margin of the Mozambique Channel, around $18.7^{\circ} \mathrm{S}$. The bank constitutes an offset in the coastline between $17-20^{\circ} \mathrm{S}$, and is characterized by an estuarine environment with a large range of salinity variability. There are records of salinity as low as 20.0 in extensive regions of the bank taken during the rainy season, when the salinity near the shelf break was slightly above 35.0 (IMR, 1978; Lutjeharms, 2006). The hydrodynamics of the channel is dominated by a number of highly variable anticyclonic eddies propagating poleward. These remarkably large eddies $(>300 \mathrm{~km}$ wide) are formed roughly every 8 weeks (i.e., 6 s 7 eddies per year) in the northern part of the channel, following a pulse in the volume transported westward by the South Equatorial Current (Backeberg \& Reason, 2010). The frequency of these mesoscale features decreases in the central and southern parts of the channel to 4 per year (Schouten et al., 2003), likely induced by anomalies emanated from the western coast of Madagascar (Huisman, 2006). Based on the transport estimates reported in the literature, deRuijter et al. (2002) and Asplin et al. (2006) have suggested that the poleward residual current at $15^{\circ} \mathrm{S}$ carries about $5 \mathrm{~Sv}(1 \mathrm{~Sv}=$ $\left.106 \mathrm{~m}^{3} \mathrm{~s}^{-1}\right)$, a significant contribution to the global thermohaline circulation. The existence of large anticyclonic eddies in the offshore region implies a modified poleward (equatorward) current along the Mozambique (Madagascar) side of the channel. According to Lutjeharms (2006), these currents induce cyclonic lee eddies when moving past a shelf offset, as it is believed to be the case in Angoche, (i.e., north of the Sofala Bank) and Delagoa Bight. Amongst other characteristics, the lee eddies are known to drive a significant upwelling at the shelf edge, which is likely to be an intermittent feature given the variability of the poleward current and leeeddy generation.

Although there is an agreement amongst researchers on the existence of different types of water in the Sofala Bank, a great deal of problems directly associated to these water masses still remains unsolved. That includes knowing the secondary characteristics of the water masses, such as their horizontal and vertical distribution, the typical concentrations of dissolved oxygen and fluorescence, the impact of these watermasses on the general and shelf circulation, the origin and fate of these watermasses, the associated stratification and mixing, the watermass impacts on 
local biogeochemical processes, and the temporal variations of watermass distributions. In this paper we limit ourselves at documenting the horizontal and vertical distribution, as well as the distribution of dissolved oxygen and fluorescence, using field data measured onboard several research vessels between 2003 and 2007.

\section{Study Site}

The Sofala Bank (Figure 1) extends from Angoche at $17^{\circ} \mathrm{S}$ to Nova Mambone at $21^{\circ} \mathrm{S}$ covering the whole coastal zone of the central Mozambique. The bank is about 20 miles wide and the area is approximately $50.000 \mathrm{~km}^{2}$. The climate along the bank is marked by a cold, dry season (April to October) and a hot, wet season (November to March). The northern part of the Sofala Bank is strongly influenced by the East African monsoon system, therefore the surface ocean circulation patterns is different from the other regions of the bank. The morphology of the coastal zone in Sofala Bank is characterized by flat terrain with an almost continuous fringe of mangroves. The seabed in the central and northern Sofala Bank is flat, and most of the industrial fishing fleets operate in this region. The water column in this region has very low salinities at the shore due to the influence of the freshwater from the Zambezi River, which discharges over $3000 \mathrm{~m}^{3} / \mathrm{s}$ on average per year Gammelsrød, 1992; Siddorn et al., 2001; Scodanibbio \& Mañez, 2005). The Zambezi annual runoff has remarkably reduced since 1978 , following the regulation of the river by Cahora Bassa dam, but it is still large enough to seasonally flood the low-lying areas. The brackish water moves over the oceanic water to a distance of $50 \mathrm{~km}$ and a depth not exceeding $15 \mathrm{~m}$. Near the Zambezi mouth, the less saline water stretches from the surface to the seabed, presumably because of the shallow nature of the bank and the combined effect of wind and tides (Lutjeharms, 2006; Nehama, 2012).

The southern Sofala Bank $\left(20^{\circ}\right.$ to $\left.21^{\circ} \mathrm{S}\right)$ is characterized by sand waves believed to be caused by the strong tidal currents, except close to the shore where the semiindustrial fleet and artisanal fishery operate with trawl-

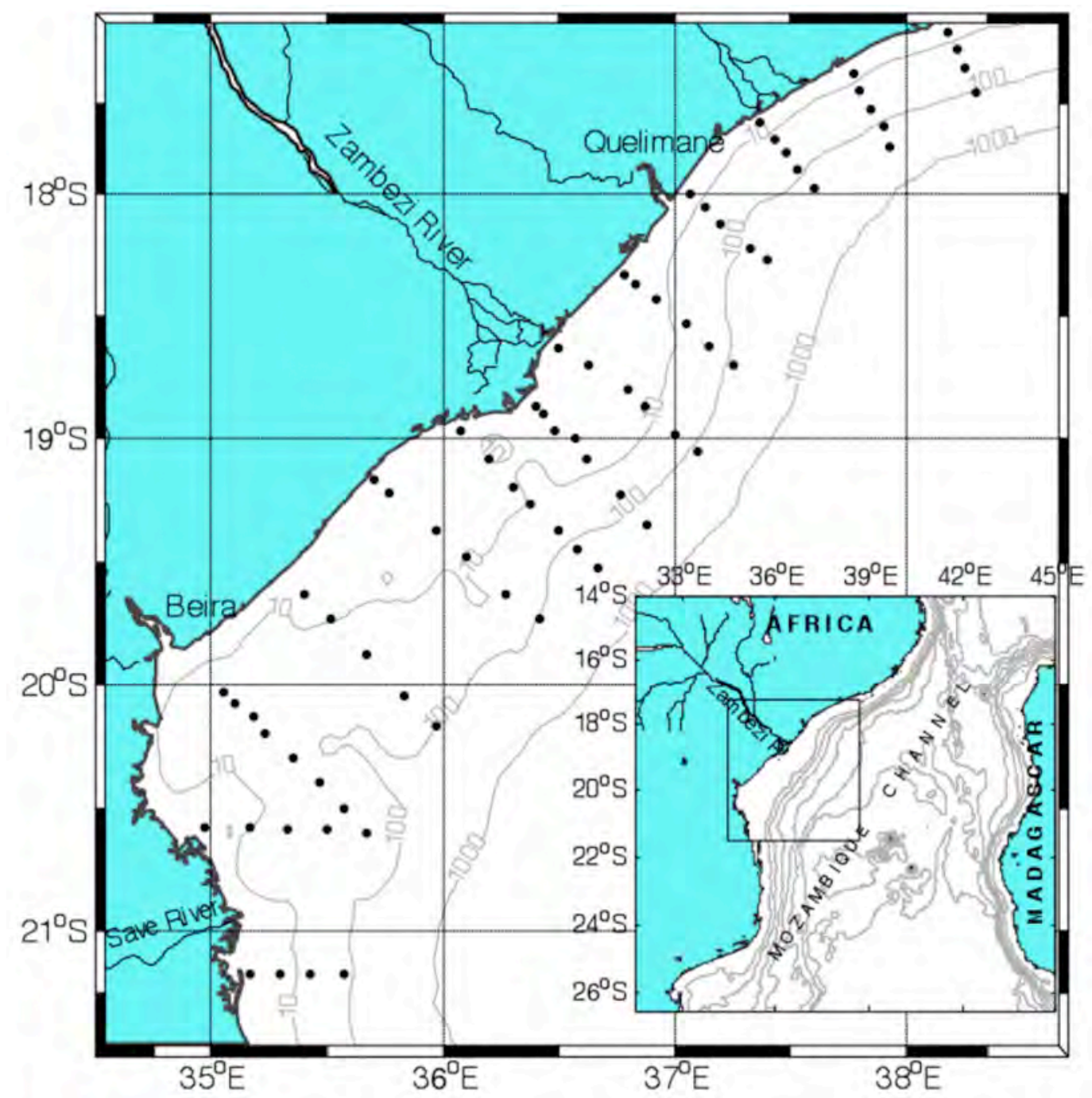

Figure 1 - Map showing study area including sampling sites

Figura 1 - Mapa que ilustra a área de estudo incluindo as estações de colheita de dados 
ing nets and beach seine, mainly targeting the shallow water shrimp (Machaieie, 2012). A large coastal area in this region is subjected to inundation by oceanic water. The salinity exceeds 36.5 as a result of extreme evaporation and evapo-transpiration in the mangrove swamps (Brinca et al., 1983; Silva, 1984). This portion of high salinity water was observed over the entire water column in shallow waters at a distance of $80 \mathrm{~km}$ from the shoreline (Brinca et al., 1983).

The Sofala Bank is known for its high productivity, which is caused mainly by the input of terrigenous nutrients through the Zambezi River, and also the extensive mangroves that provide shelter (nursery) for important fisheries and shellfish. The main fish species are Scads (Decapterus russelli), occurring in abundance at depth of 20 to $90 \mathrm{~m}$; Carangoides malabaricus that occurs between 10 and $100 \mathrm{~m}$ deep; anchovies (Stolephorus spp), which occurs between 20 and $60 \mathrm{~m}$ deep; sardines (Pellona ditchela and Thryssa vitrirostris) occurring at depths less than 20 meters; Leiognathus equulus, Insidiator Secutor, Etrumeus teres and Hilsa kelee that occur near the coast and in estuaries (Saetre \& Silva, 1979; Brinca et al., 1983; Machaieie, 2012).

\section{Hydographic data and methods}

In this study, hydrographic data measured by a CTD probe were analysed. The data was collected on cruises conducted by the Mozambican National Institute for Fisheries Research (IIP), between the years 2003 and 2007 in Sofala Bank, using vessels from the semiindustrial shrimp fishery fleet. For each year, the hydrographic measurement covered 73 stations (Figure 1) over a period of about 15 days, and these stations were interspersed with sampling of shrimp recruitment. The design of the station network allowed for a minimum distance between stations of $5 \mathrm{~km}$, and the furthermost station in each transect was located along the $100 \mathrm{~m}$ isobath, which in some cases corresponds to a distance from the coast of above $100 \mathrm{~km}$. The probe (CTD seabird 19plus) was in many occasions coupled to other sensors, namely turbidity (D\&A OBS), dissolved oxygen (Beckman/YSI) and fluorescence (Wetlab wetStar), except for cruise conducted in 2003 that had only the standard probe sensors (temperature, salinity and pressure). At each station, the sampling started as close as possible to the surface, and subsequent readings were taken every half a second and averaged every 2 dbars.

The density of water at each station was calculated after landing using the Equation of State established in 1980 (UNESCO, 1983) and the atmospheric pressure. Distances between stations was determined using a Matlab code specifically designed for that purpose, which uses simple geometry principles, and stations located along a line crossing the shoreline
The data analysis consisted of visual inspection of the salinity and temperature properties of all dataset, combined with one-way analysis of variance (ANOVA) for unbalanced data following the description in Chambers (1992).

\section{Results}

The water masses are described and discussed here in terms of a vector with two components, salinity and temperature. Figure 2 presents the water types observed around Sofala Bank from 2003 to 2007. Based on this T-S diagram one can identify four water masses with different properties. For the sake of simplicity and clarity these water masses will be called $\mathbf{A}, \mathbf{B}, \mathbf{C}$, and D. The water mass A corresponds to water with salinity below 32.5 and temperatures ranging from 27.5 to $31.5^{\circ} \mathrm{C}$, which is within the limit for a tropical estuarine plume with strong influence of freshwater discharges (Simpson, 1997; and the references therein); The water mass B has salinity levels between 32.5 and 36.5 and similarly high temperatures (between 26.5 and $31.5^{\circ} \mathrm{C}$ ); While the water mass $\mathbf{C}$ presents high salinity values varying in a narrow range (34.5 and 35.5$)$ and have low temperatures $\left(14\right.$ to $\left.26.5^{\circ} \mathrm{C}\right)$; The water mass D has high salinity levels (over 35.5 ) and highly varying temperatures $\left(15-27.5^{\circ} \mathrm{C}\right)$.

Analysis of variance (ANOVA) was carried out to verify whether significant differences exist among the salinity and temperature of the four water masses. The one-way ANOVA results showed that all physical properties listed in table 1 have significant differences $(p<0.01)$ between the four water types, with the mean salinity increasing while mean temperature decreased from water type A though D. Specifically, the Tukey's test identified significant differences $(p<0.01)$.

To examine the variability of water masses in terms of their cross-shelf location, the distance of sampling station in relation to the coast was calculated suing the latitude and longitude coordinates, and then all dataset was grouped into water types and inspected. Figure 3 presents the across-shelf distribution of the four water masses, showing the salinity against the location of occurrence at the coast. As can be seen, water masses A, B and C can be found from the coast to $140 \mathrm{~km}$ offshore. The water mass $\mathbf{D}$ is not present near the coast and it extends offshore from $40 \mathrm{~km}$. The maximum salinity values $(>36.5)$ occur between $80-100 \mathrm{~km}$ from the coast.

Figures 4 and 5 present the variations of the dissolved oxygen and fluorescence for each water mass as a function of distance to coast. Data for water mass $\mathbf{D}$ is missing because this water mass only appeared in the 2003 dataset, and coincidentally, oxygen and fluorescence were not recorded in that year. Similarly, 


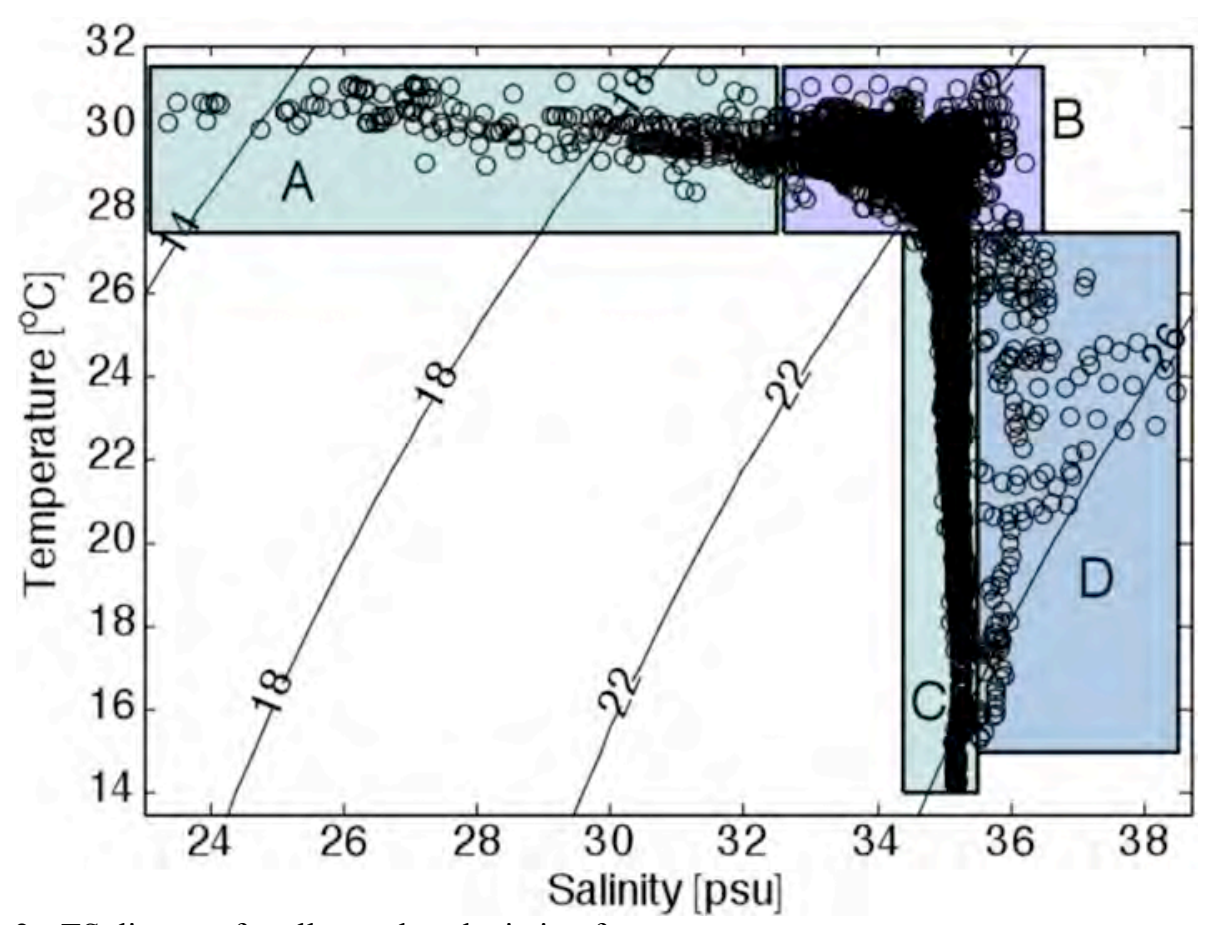

Figure 2 - TS diagram for all samples, depicting four water masses.

Figura 2 - Diagrama TS para todas amostras, ilustrando quatro distintas massas de água.

Table 1 - Average values of the variables for each water mass and results of one-way ANOVA, for critical $\mathrm{p}<0.01$, and Tukey test for unbalanced data between water masses. The significant values $(\mathrm{p}<0.01)$ are in bold.

Tabela 1 - Valores médios dos parâmetros para cada massa de água e resultados da analise de variância para um valor crítico de $\mathrm{p}<0.01$, e o resultado do teste de Tukey entre as massas de água para dados não uniformes. Os valores significantes $(\mathrm{p}<0.01)$ aparecem em negrito.

\begin{tabular}{|l|r|r|r|r|r|r|}
\hline Parameter & Type A & Type B & Type C & Type D & F calculated & $p$ value \\
\hline Salinity $(\mathrm{psu})$ & 29.05 & 34.72 & 35.14 & 36.18 & $\mathbf{5 1 1 2 . 0 0}$ & $\mathbf{0 . 0 0}$ \\
\hline Temperature $\left({ }^{\circ} \mathrm{C}\right)$ & 29.96 & 29.00 & 23.44 & 22.75 & $\mathbf{4 7 9 7 . 0 0}$ & $\mathbf{0 . 0 0}$ \\
\hline Depth $(\mathrm{m})$ & 3.90 & 14.66 & 64.87 & 59.40 & $\mathbf{3 1 3 2 . 0 0}$ & $\mathbf{0 . 0 0}$ \\
\hline Distance $(\mathrm{km})$ & 31.04 & 60.05 & 65.78 & 102.79 & $\mathbf{2 0 3 . 8 0}$ & $\mathbf{0 . 0 0}$ \\
\hline Oxygen $(\mathrm{mL} / \mathrm{L})$ & 16.70 & 16.72 & 13.55 & 15.73 & $\mathbf{8 6 5 . 7 0}$ & $\mathbf{0 . 0 0}$ \\
\hline Fluorescence $\left(\mathrm{mg} / \mathrm{m}^{3}\right)$ & 1.88 & 1.72 & 2.03 & 2.83 & $\mathbf{2 6 . 8 8}$ & $\mathbf{0 . 0 0}$ \\
\hline
\end{tabular}

the data points in figures 4 and 5 are relatively lower than those presented in Fig.3 because the dissolved oxygen and fluorescence sensors were turned off in some cruises. As can be seen, the distribution of both dissolved oxygen and fluorescence differs considerably in the recorded water masses; however, there is no clear trend for the relationship of these two parameters with the distance to shoreline. The water mass A has very high values of dissolved oxygen (13-20 mL/L) and low values of fluorescence (1-4 mg/m3), while for the masses $\mathbf{B}$ and $\mathbf{C}$ the range of values is greater for oxygen $(7$ to $21.6 \mathrm{~mL} / \mathrm{L})$ and fluorescence $(0.01$ to $11 \mathrm{mg} / \mathrm{m} 3)$.

In order to investigate the vertical distribution of water masses, the data for each water mass were grouped according to their properties and plotted against depth.
Figures 6, 7 and 8 illustrate the variation in salinity, dissolved oxygen, and fluorescence of each water mass, respectively. Water masses $\mathbf{A}$ and $\mathbf{B}$ are located in the upper $18 \mathrm{~m}$ and $70 \mathrm{~m}$ of the water column, respectively. This pattern suggests that these masses either move over denser water, or are distributed throughout the water column in shallow areas. The water masses $\mathbf{C}$ and D are not present in the first few meters at the surface, and they can only be found from the $5 \mathrm{~m}$ or $15 \mathrm{~m}$ depth towards the seabed, respectively. The region of maximum salinity $(>36.5)$ in the water mass $\mathbf{D}$ is located between the $30 \mathrm{~m}$ and $65 \mathrm{~m}$ depth. Dissolved oxygen has its maximum and minimum values at the surface in the water masses $\mathrm{A}$ and $\mathrm{B}$, and the range slightly decreases with depth. The dissolved oxygen in 

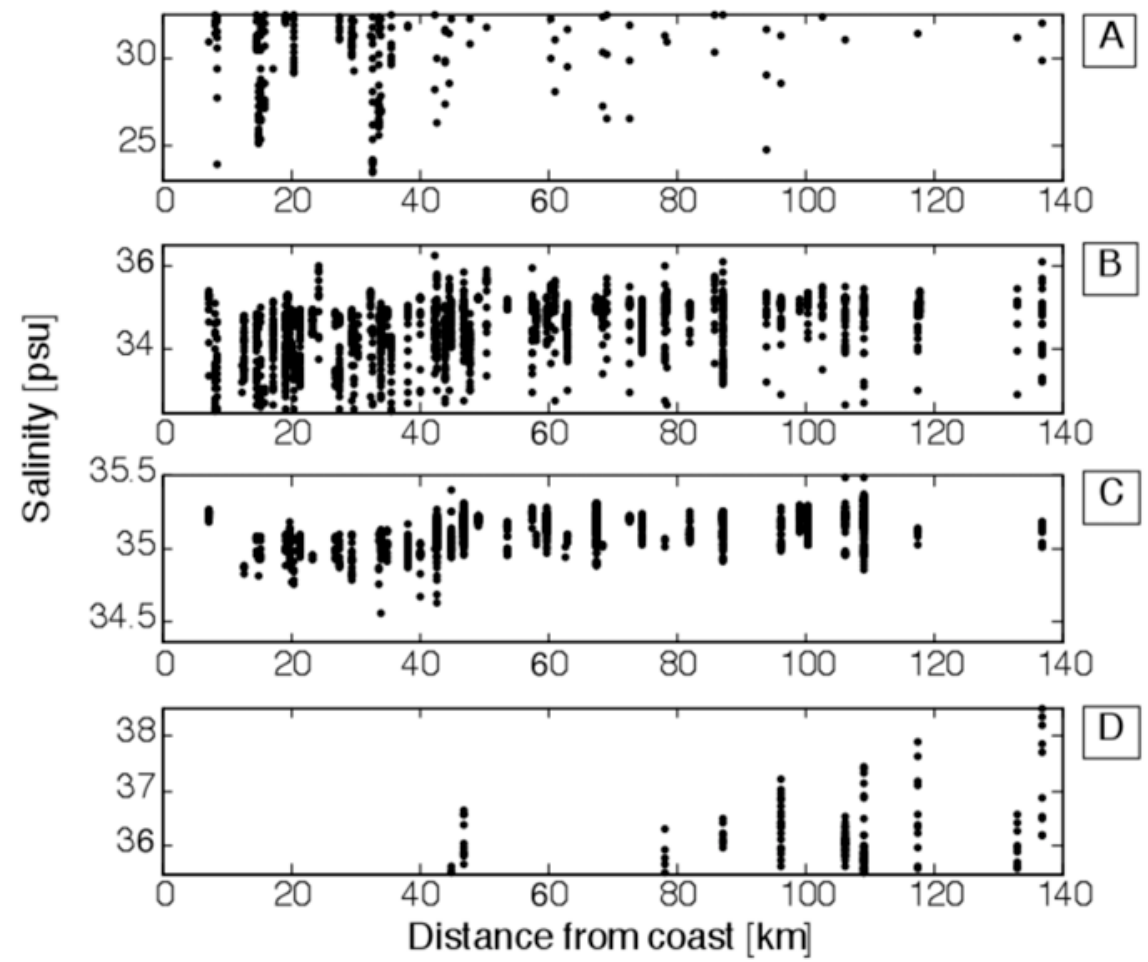

Figure 3 - Variation of salinity with across-shelf distance for water masses $\mathbf{A}, \mathbf{B}, \mathbf{C}$ and $\mathbf{D}$.

Figura 3 - Variação da salinidade em função da distancia para as massas de água A, B, C e D.

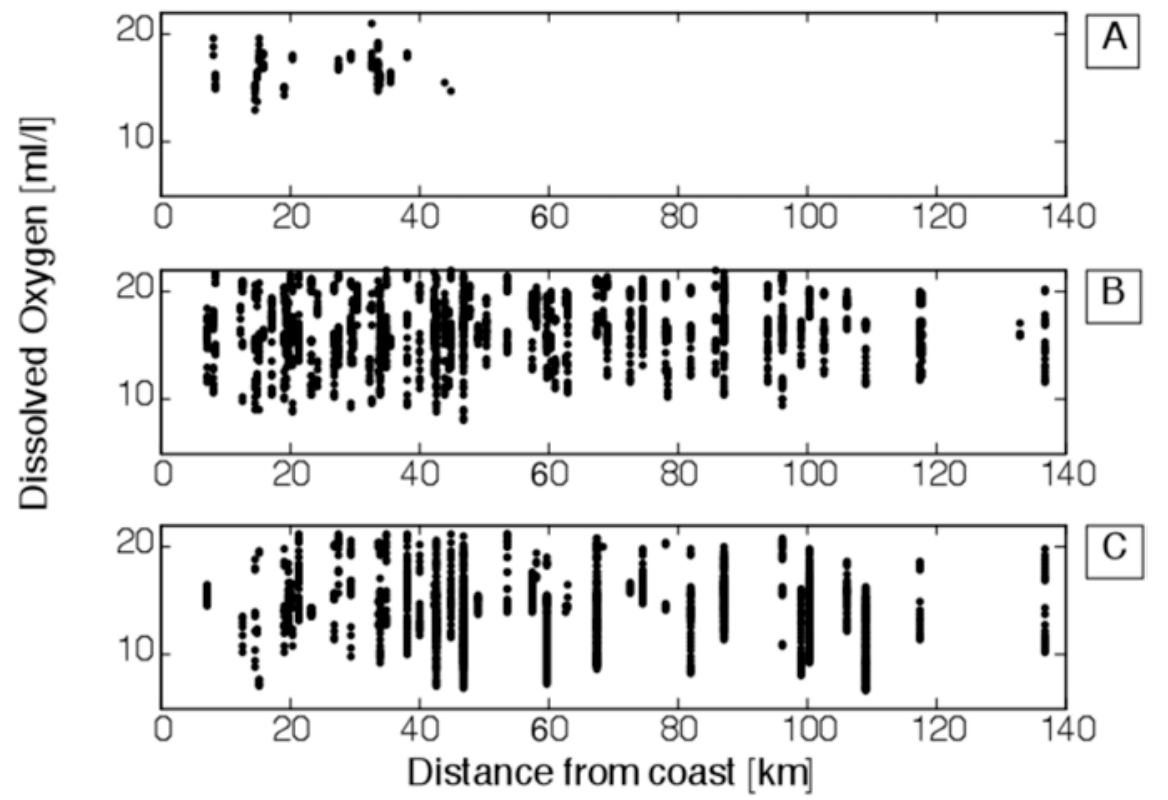

Figura 4 - Variation of dissolved oxygen with across-shelf distance for the water masses $\mathbf{A}, \mathbf{B}$, and $\mathbf{C}$.

Figura 4 - Variação do oxigênio dissolvido em função da distancia para massas de agua $\boldsymbol{A}, \boldsymbol{B}, \boldsymbol{e}$.

the water mass $\mathrm{C}$ is low near the surface, a maximum value occurs between $20 \mathrm{~m}$ and $50 \mathrm{~m}$ depth, and it tends to a minimum value at location deeper than $100 \mathrm{~m}$. On the other hand, the fluorescence decreases with depth in general, and the maximum value occurs between 20 and 50 m depth.

\section{Discussion}

Based on the T-S diagram presented in Figure 2, four water masses that are mainly different in their salinity were identified in the Sofala Bank. The salinity has a greater impact on the description of water masses (Duxbury and Duxbury, 1997), given that it is the factor influencing the seawater density the most in the tropical regions with strong freshwater influence, as opposed to temperate regions where the strong seasonal heating cycle controls the density variations (Simpson, 1997). Low salinity (23-32.5) shelf waters having high temperatures $\left(27-31^{\circ} \mathrm{C}\right)$ were recorded over the Sofala Bank. The occurrence of this water mass is consistent 


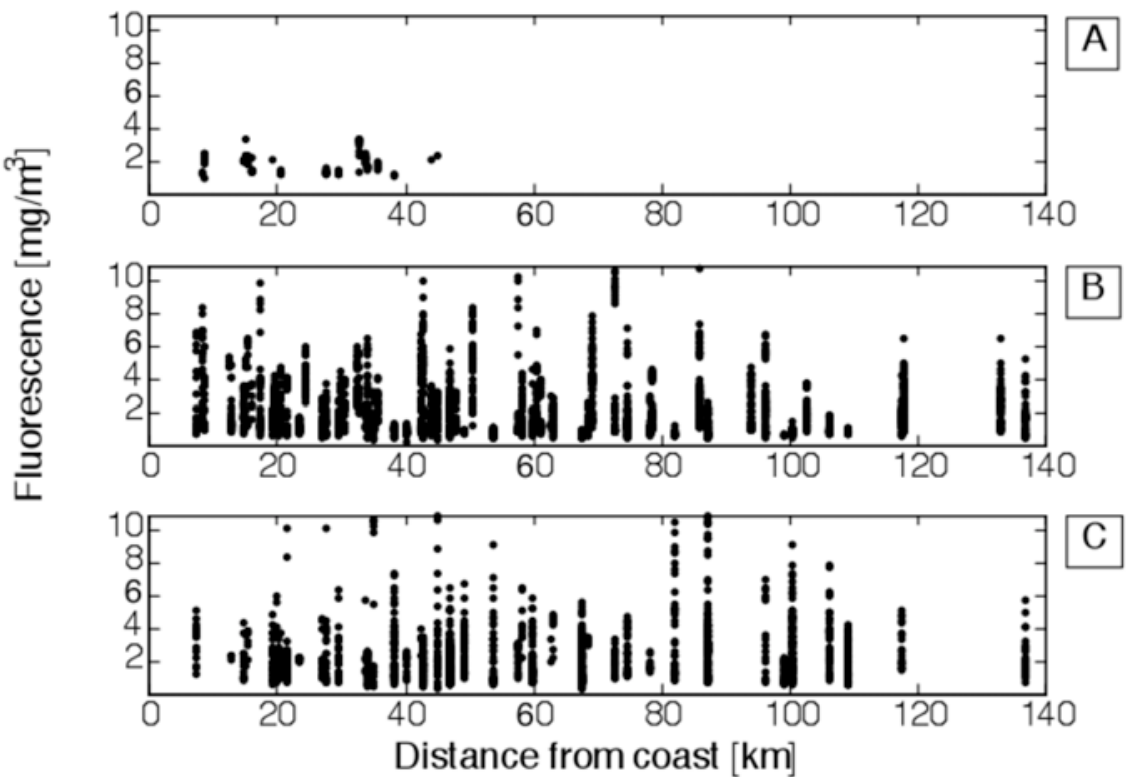

Figure 5 - Variation of fluorescesce with the across-shelf distance for water masses $\mathbf{A}, \mathbf{B}$ and $\mathbf{C}$.

Figura 5 - Variação da fluorescência com a distância para massas de água $\boldsymbol{A}, \boldsymbol{B}$ e $\boldsymbol{C}$.

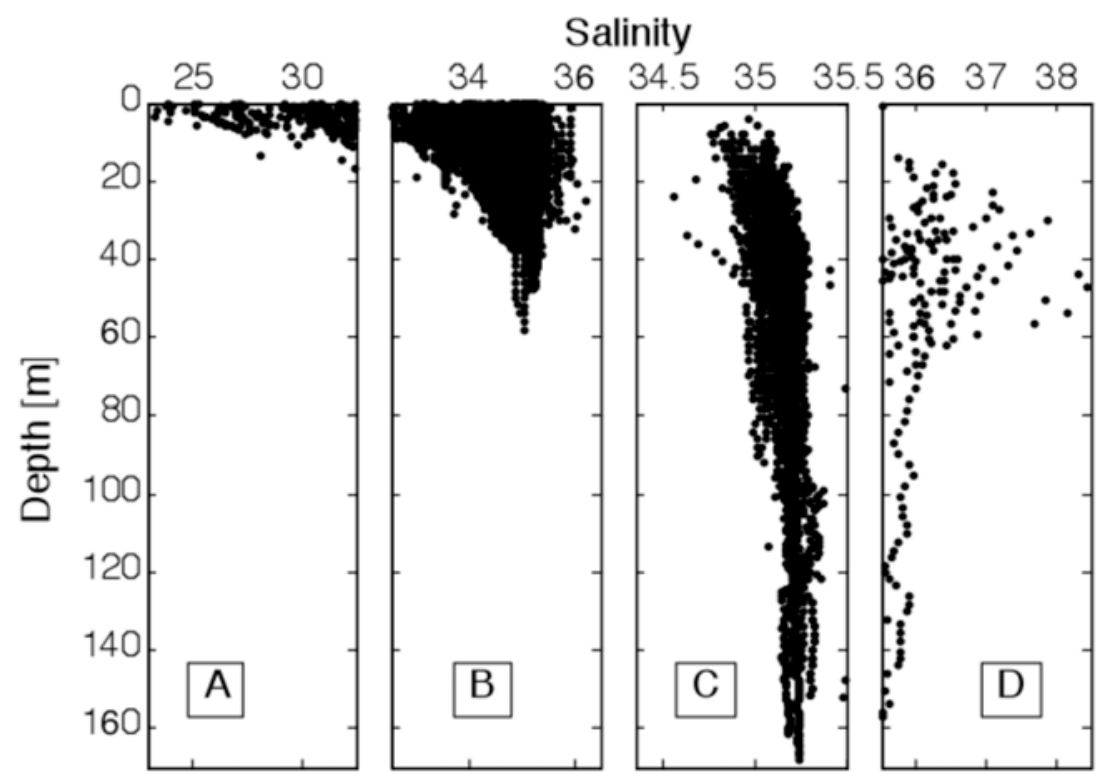

Figure 6 - Vertical distribution of salinities in water masses A, B, C, and $\mathbf{D}$ based on data collected between 2003 and 2007.

Figura 6 - Variação vertical da salinidade das massas de água A, B, C e D no Banco de Sofala, a partir dos dados do cruzeiro do IIP no período de 2003 a 2007.

with the known physical characteristics of the study site, given that the Sofala Bank is a recipient of freshwater discharges from a number of rivers, including the Pungwe, Buzi and Zambezi rivers. The latter contributes a great deal in terms of buoyancy input to the coastal ocean. According to the results presented here, the low salinity shelf water is limited to the upper $15 \mathrm{~m}$ of depth and spreads horizontally beyond $100 \mathrm{~km}$ from the coast. It covers the regions surrounding the river mouths (Silva, 1984; Machaieie, 2012), and the area of the plume Zambezi River (Nehama, 2012).

The water masses identified in this study are comparable with those previously described by Silva (1984),
Gammelsrod \& Hoguane (1995), and Machaieie (2012). These authors observed only three water masses in the Sofala Bank region area, namely: low salinity shelf water (LSSW) with high temperatures, which is comparable to the water mass $\mathbf{A}$; oceanic water $(\mathrm{OW})$ with relatively high salinity and low temperatures that matches the water mass $\mathbf{C}$; and high salinity shelf water (HSSW) that matches the mass D. According to Siddorn et al. (2001), the water mass B, absent in these two earlier studies, refers to the oceanic surface water not influenced by the freshwater discharges, yet having higher temperatures than the water mass $\mathbf{C}$. This water mass can be found over the entire breadth of the bank 


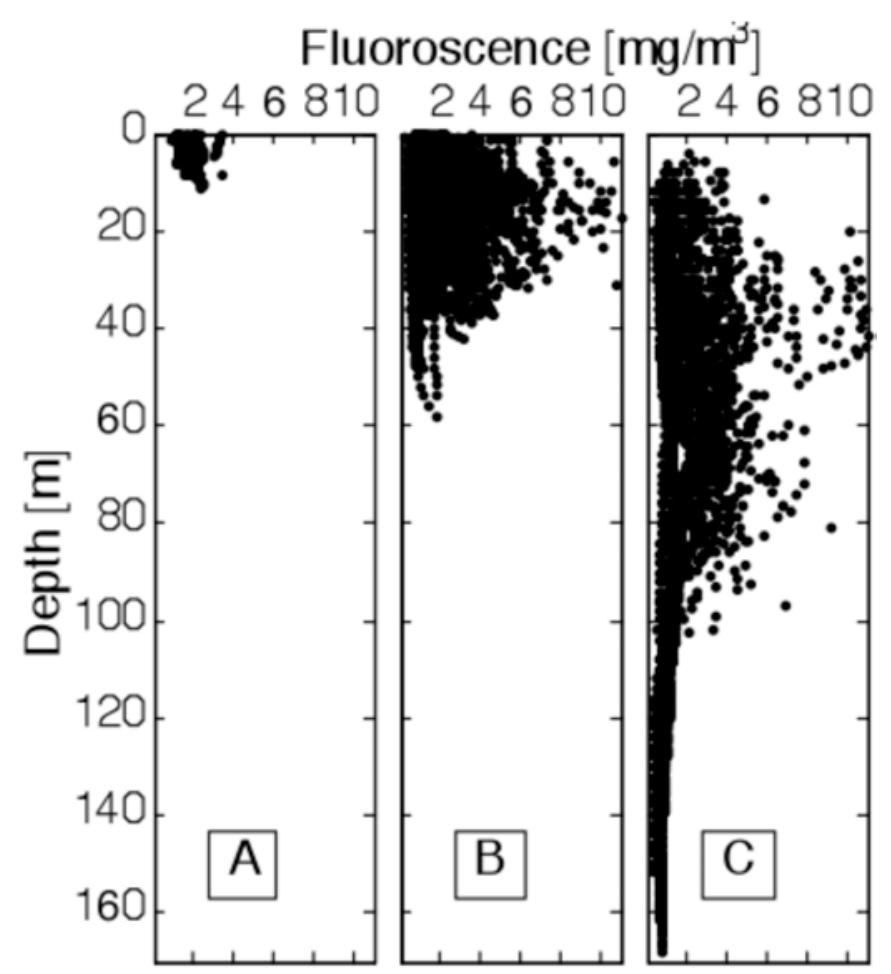

Figure 7 - Vertical distribution of dissolved oxygen in three water masses.

Figura 7 - Distribuição vertical do oxigénio dissolvido em três massas de água.

$(0-140 \mathrm{~km})$ and is limited to the upper $70 \mathrm{~m}$ of the water column. In those earlier studies, the type $C$ water was considered to be part of either type A or type C water, however, the ANOVA results indicated that the water samples A, B, C, and D all came from different groups. Brinca et al. (1983) and Silva (1984) reported the occurrence of high salinity $(>35.4)$ shelf water along the coast around latitude $20^{\circ} 20 \mathrm{~S}$ over the entire water column. In this study, high salinity water $(>36.5)$ presented in Figure 3-D was found beyond $80 \mathrm{~km}$ from the coast, at about $50 \mathrm{~m}$ depth (Figure 6-D). It is believed though, that we are dealing with same water mass, where the differences in location could have been induced by some form of natural variability in time and space. In that report, the authors (Brinca et al., 1983) argued using simple transport calculations that the occurrence of this water mass could not be justified only by the increased evapotranspiration rates estimated for the mangrove areas. Additional hydrographic measurements taken in 2003 and presented in this study reinforce the idea that the origin of these hypersaline waters still needs to be determined.

The entire region of the Sofala Bank is in general well oxygenated, with values around $20-22 \mathrm{~mL} / \mathrm{L}$ of dissolved oxygen at the surface and $5-7 \mathrm{~mL} / \mathrm{L}$ at greater depths. No clear pattern of the variation of both dissolved oxygen and fluorescence with distance to the coast was found. This suggests that for a fixed depth the

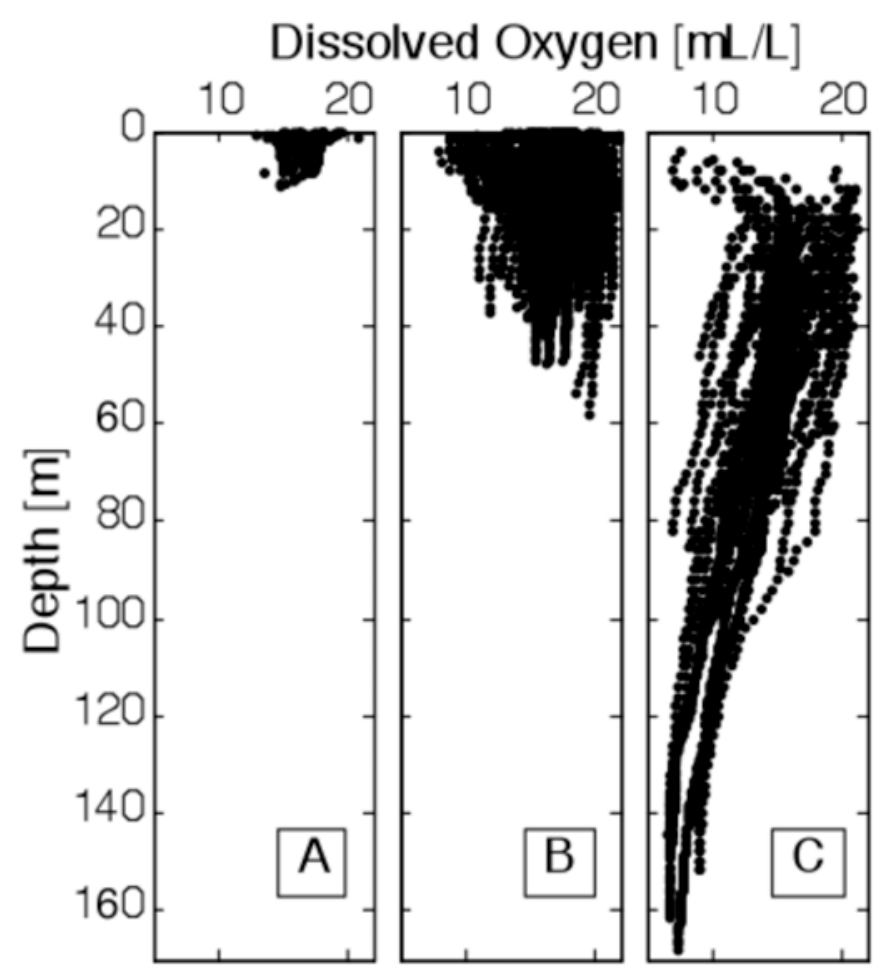

Figure 8 - Vertical distribution of fluorescence.

Figura 8 - Distribuição vertical da fluorescência.

four identified water masses cannot be distinguished by their content of dissolved oxygen. Moreover, this pattern indicates that any activity of respiration or oxidation of organic material occurs homogeneously in the whole bank. The oxygen concentration was never lesser than $12 \mathrm{~mL} / \mathrm{L}$ in the water mass $\mathrm{A}$, which is noticeably influenced by the rivers. A typical vertical profile of dissolved oxygen in the open ocean is one which high values occur near the surface because the atmosphere is the main source for oxygen (Pickard \& Emery, 1990). Super-saturation can occur in this layer due to the additional input of oxygen from photosynthesis. The profiles of dissolved oxygen presented here display the typical decrease in concentration with depth, and also point to a great variability for a given depth or distance to coast, which in turn highlights the need for further analysis. Santos et al. (2008) analysed abiotic parameters within the extent of the Amazon River plume and found dissolved oxygen in concentrations of about $5 \mathrm{~mL} / \mathrm{L}$ corresponding to saturated to supersaturated environments. Provided that a direct comparison with those measures cannot established, it can only be speculated that the concentrations of dissolved oxygen reported for Sofala Bank presented in Figures 4 and 7 might be above the limit of saturation. In general, higher values of fluorescence were observed below the sub-surface layer and the stations where depth exceeds $100 \mathrm{~m}$, the fluorescence at the seabed is about $10 \%$ that of the surface. This type of distribution pattern has been 
observed before in other parts of the Mozambique Channel (Langa, 2011), and is related to nutrient distribution and light penetration.

There are great examples in the literature of physical control to recruitment of various species, as a consequence of the transport of water with particular characteristics from the shore or towards the shore. For instance, Parnell (2001) used the recruitment of different species to associate larval species with particular estuarine water, and Farrell et al. (1991) found large recruitment in the intertidal region associated with the advection of warm, clear, and low-salinity water into nearshore region. The presence of four different water masses in the Sofala Bank has ecological and management implications that still needs to be thoroughly investigated. There is a clear linkage between the runoff and shrimp catch rates (Gammelsrod, 1992; Hoguane, 1997), which has direct implications on the management of shrimp resources. We still need to understand whether the variations and transport of the three other oceanic water masses cause changes in the living resources in the bank.

\section{Conclusions}

Four water masses were identified along the Sofala Bank, namely, low salinity shelf water, $(<32.5 \mathrm{psu}$ and $\left.28-31^{\circ} \mathrm{C}\right)$, surface warmer oceanic water $(32.5-35.8 \mathrm{psu}$ and $\left.27.5-31^{\circ} \mathrm{C}\right)$, deep oceanic water $(34.5-35.5 \mathrm{psu}$ and $\left.15-27.5^{\circ} \mathrm{C}\right)$, and high salinity shelf water $(>35.5 \mathrm{psu})$. The variance of the water masses was tested statistically using ANOVA and Tukey test and a significant difference was found $(p<0.01)$. The direct influence of river runoff as evidenced by the presence of low salinity waters in the shelf is limited to a narrow strip of around $50 \mathrm{~km}$ and to the upper $15 \mathrm{~m}$ of the water column, which in some cases correspond to entire water column. The high salinity shelf water extends offshore from $38 \mathrm{~km}$ at a depth greater than $15 \mathrm{~m}$. All water masses are generally well oxygenated and the lower limit of dissolved oxygen decreases with depth but is homogeneous over the bank's breadth. This lower limit corresponds to 13,7 and $5.7 \mathrm{~mL} / \mathrm{L}$ for the low salinity shelf water, surface oceanic water, and high salinity water, respectively. Fluorescence is in general low and almost uniform over the low salinity shelf water, but in the two oceanic waters (i.e., having high and low temperatures) it presents low values at the surface and higher values immediately below the surface layer. The presence of four different water masses in the Sofala Bank is likely to have ecological and management implications.

\section{Acknowledgements}

F.Nehama received an IFS grant (w5384-1) to undertake this research. The authors acknowledge Dr. Bernardino Malauene from IIP for his assistance in gathering the hydrographic data, and two anonymous reviewers, whose contributions changed significantly the quality of the manuscript.

\section{References}

Asplin, L.; Skogen, M.D.; Budgell, W.P.; Gammelsrød, T.; Dove, V.; Andre, E.; Hoguane, A.M. (2006) - Numerical modelling of currents and hydrography in Mozambique Channel. Revista de Investigação Pesqueira, 25, Instituto de Investigação Pesqueira, Maputo, Moçambique.

Backeberg, B.; Reason, C.J.C. (2010) - A connection between the South Equatorial Current north of Madagascar and Mozambique Channel eddies. Geophysical Research Letters, 37(4):L04604 [6p.]. DOI: 10.1029/2009GL041950.

Brinca, L.; daSilva, A.J.; Sousa, L.P.; Sousa, I.M.; Saetre, R. (1983) - A survey of the fish resources at Sofala Bank-Mozambique, September 1982. Reports on surveys with the R/V Dr. Fridtjof Nansen. 70p., Technical Report, Instituto de Investigação Pesqueira, Maputo, Mozambique. Unpublished.

Brinca, L.; Mascarenhas, V.; Sousa, B.P.; Sousa, L.P.; Sousa, I.M.; Saetre, R.; Timochin, I. (1984) - A survey of the fish resources at Sofala Bank -Mozambique May - June 1983. Reports on surveys with the R/V Dr. Fridtjof Nansen. 91p., Technical Report, Instituto de Investigação Pesqueira, Maputo, Mozambique. Unpublished.

Chambers, J.M. (1992) - Linear models. In: J. M. Chambers \& T. J. Hastie (eds.), Statistical Models in S, pp. 95-144, Wadsworth \& Brooks/Cole Advanced Books and Software . Pacific Grove, CA, U.S.A. ISBN: 0534167640.

deRuijter, W.P.M.; Ridderinkhof, H.; Lutjeharms, J.; Schouten, M.W.; Veth, C. (2002) - Observations of the flow in the Mozambique Channel. Geophysical Research Letters, 29(10):140[3p.]. DOI: 10.1029/2001GL013714

Duxbury, A.C.; Duxbury, A.B. (1997) - An Introduction to the Word's Oceans. 5th edition, 503p., Win. C. Brown Publishers, London, U.K. ISBN: 0697282732.

Farrell, T.M.; Bracher, D.; Roughgarden, J. (1991) - Cross-shelf transport causes recruitment to intertidal populations in central California. Limnology and Oceanography, 36(2):279-288. DOI: 10.4319/1o.1991.36.2.0279.

Ferreira, A.P.; Horta, M.A.P.; Cunha, C.L.N. (2010) - Avaliação das concentrações de metais pesados no sedimento, na água e nos órgãos de Nycticorax nycticorax (Garça-da-noite) na Baía de Sepetiba, RJ, Brasil. Revista da Gestão Costeira Integrada / Journal of Integrated Coastal Zone Management, 10(2):229241. DOI: $10.5894 /$ rgci186

Gammelsrød, T. (1992) - Variation in shrimp abundance on the Sofala bank, Mozambique, and its relation to the Zambezi river runoff. Estuarine and Coastal Shelf Science, 35(1):91-103. DOI: 10.1016/S0272-7714(05)80058-7.

Gammelsrød, T.; Hoguane, A.M. (1995) - Watermasses, currents and tides at Sofala Bank, November 1987. Revista de Investigação Pesqueira, 22:37-60, Instituto de Investigação Pesqueira, Maputo, Moçambique.

Hoguane, A.M. (1997) - Shrimp abundance and river runoff in Sofala Bank - The rule of Zambezi. Paper presented in the workshop on sustainable use of the Cahora Bassa Dam, 16p., Songo, Mozambique. Unpublished.

Hoguane, A.M. (2007) - Perfil Diagnóstico da Zona Costeira de Moçambique. Revista da Gestão Costeira Integrada / Journal of Integrated Coastal Zone Management 7(1):69-82. DOI: 10.5894/rgci11

Huisman, S. (2006) - Kelvin and Rossby wave interactions at Midlatitudes: The cause for decreasing dominant mesoscale fre- 
quency in the Mozambique Channel. 64p., Master thesis, Institute for Marine and Atmospheric Research, Utrecht. Unpublished.

IMR, (1978) - Cruise report No. 4 of $R / V D r$. Fridtjof Nansen, April-June 1978. Joint NORAD/Moçambique/FAO project to investigate the fish resources off the coast of Moçambique. 49p. Technical Report, Institute of Marine Research, Bergen, Norway. Unpublished.

Lalli, C.M.; Parsons, T.R. (1997) - Biological Oceanography - an Introduction. $2^{\text {nd }}$ edition, $314 \mathrm{p}$., the Open University, Butterworth-Heinemann, Great-Britain. ISBN: 0750633840.

Langa, A.A.A. (2011) - Eddy variability and their influence on the primary productivity in the Mozambique Channel. 56p., Master thesis, University of Dar es Salaam, Dar es Salaam, Tanzania. Unpublished.

Lutjeharms, J.R.E. (2006) - The coastal oceans of south-eastern Africa. Vol. 14B, 810p., Harvard University Press, Cambridge, U.K. ISBN: 978-0674021174.

Machaieie, H.A. (2012) - Water Masses, Circulation, Stratification And Fronts in Sofala Bank, 38p., Master thesis, Eduardo Mondlane University, Quelimane, Moçambique. Unpublished.

Malauene, B.S. (2005) - Circulação Geostrófica e Massas de Água na Baía de Bazaruto. 36pp., Trabalho de Licenciatura, Universidade Eduardo Mondlane, Maputo, Mozambique. Available on-line at http://www.saber.ac.mz/handle/10857/347.

Nehama, F.P.J. (2012) - Modelling the Zambezi River plume using the Regional Oceanic Modelling System. 177p., PhD thesis, Universidade de Cape Town. Africa do Sul. Unpublished.

Parnell, P.E. (2001) - The distribution of estuarine and oceanic water masses on the southern shore of O'ahu, Hawai'i: Ecological and coastal management implications, a novel methodology. Limnology and Oceanography, 46(6):1468-1485. DOI: 10.4319/lo.2001.46.6.1468.

Pickard, G.L.; Emery, W.J. (1990) - Descriptive physical oceanography: an introduction. $5^{\text {th }}$ edition, 336p., Pergamom Press, U.K. ISBN: 978-0750627597.

Saetre, R.; Silva, R.P (1979) - The marine fish resources of Mozambique. Reports on surveys with R/V Dr. Fridtjof Nansen. 179p.,
Technical report, Serviços de Investigação Pesqueira, Maputo, Mozambique and Institute of Marine Research, Bergen, Norway.

Santos, C.; Barreiros, A.; Pestana, P.; Cardono, A.; Freire, A. (2011) - Environmental status of water and sediment around submarine outfalls - west coast of Portugal. Revista da Gestão Costeira Integrada / Journal of Integrated Coastal Zone Management, 11(2):207-217. DOI: $10.5894 /$ rgci243

Santos, M.L.S.; Muniz, K.; Barros-Neto, B.; Araujo, M. (2008) Nutrient and phytoplankton biomass in the Amazon River shelf waters. Anais da Academia Brasileira de Ciencias, 80(4):703717. DOI: $10.1590 / \mathrm{S} 0001-37652008000400011$.

Schouten, M.W.; de Ruijter, W.P.; van Leeuwen, P. J.; Ridderinkhof, H. (2003) - Eddies and variability in the Mozambique Channel. Deep-Sea Research II, 50(12-13):1987-2003. DOI: 10.1016/S0967-0645(03)00042-0.

Scodanibbio, L.; Mañez, G. (2005) - The World Commission on Dams: A fundamental step towards integrated water resources management and poverty reduction? A pilot case in the lower Zambezi, Mozambique. Physics and Chemistry of the Earth, Parts $\quad A / B / C, \quad 30(11-16): 976-983 . \quad$ DOI: 10.1016/j.pce.2005.08.045.

Siddorn, J.R.; Bowers, D.G.; Hoguane, A.M. (2001) - Detecting the Zambezi River Plume using observed optical properties. Marine Pollution Bulletin, 42(10):942-950. DOI: 10.1016/S0025326X(01)00053-4.

Silva, A.J. (1984) - Hydrology and fish distribution at the Sofala Bank (Mozambique). Revista de Investigação Pesqueira,12:536, Instituto de Investigação Pesqueira, Maputo, Moçambique..

Simpson, J.H. (1997) - Physical processes in the ROFI regime. Journal of Marine Systems, 12(1-4):3-15. DOI: 10.1016/S09247963(96)00085-1.

UNESCO (1983) - Algorithms for computation of fundamental properties of seawater. 53p., UNESCO Technical paper in Marine Science, No. 44. Available online at http://unesdoc.unesco.org/images/0005/000598/059832eb.pdf 